\title{
PERSPEKTIEF
}

\section{DIE EEUFEES EN DIE TOEKOMS}

Die eeufees van die P.U. vir C.H.O. vanjaar bring verskillende belangrike fasette na vore: die nederige en beskeie begin van die Universiteit, die formele besluit in geloof geneem wat ontplooi tot ' $n$ magtige werklikheid, die onverstaanbare insig van die stigters m.b.t. die moontlikhede in die toekoms. Al hierdie gedagtes is beliggaam in verskillende geskrifte wat tydens die eeufees verskyn; wanneer hulle saam gelees word is dit of die panorama van die ontstaan, groei en volwassewording van die Universiteit voor mens oop le. Vir almal wat aan die ideaal van ' $n$ Christelike Universiteit verbonde is, is dit 'n ver. kwikking en versterking op die pad vorentoe.

Daar is in hierdie pragtige blomtydperk van ' $n$ eeufees egter een element wat mens tot nadenke dwing en te midde van al die feestelikheid ' $n$ ernstige oomblik besorg: ' $n$ fees het by sy heerlike opwindende karakter die kenmerk van kortstondig. heid. Haas is die fees verby, die genot van al die verrigtinge is iets van die verlede, die eenmalige literatuuroes is ingesamel. Maar hierby kan nie volstaan word nie - die ontwikkeling van dag tot dag in die groot momente en in die skynbaar klein momente moet voortgaan. Daar is nie geleentheid vir ontspanning in hierdie lewensbelangrike werksaamheid nie. In die klaskamers, vanaf die verhoë, in die sale van ons land moet gebou word op die beginsels wat nou vir honderd jaar as basis dien van hierdie Universiteit. Maar in geskrif moet die gedagtegange op die proef gestel en ontwikkel word. In 'n Christelike universiteit is daar nie ruimte vir stagnasie nie, net vir dinamiese en goedbeplande vooruitgang.

Vir 'n tydskrif soos ,Koers" is dit 'n voorreg om vir ses-en-dertig jaar op wetenskaplike vlak die draer te wees van ons diepste denke oor al die probleme aan ' $n$ universiteit op die verskillende vakgebiede. Geen enkele tydskrif kan in hierdie opsig met "Koers" vergelyk word nie. Maar laat ons nie 
in 'n ydele trots bly steek nie. 'n Nuwe eeu lê voor die deur en ons poging om die stem van die P.U. vir C.H.O. op te vang moet baie verbeter word in die eersvolgende jare.

Die tyd is egter verby dat ons op ' $n$ paar voor die hand liggende en uitgesoekte rigtings kan konsentreer. Die Universiteit in sy hele omvang moet in die blad se inhoud betrek word. Hieruit volg dat elke artikel nie noodwendig met soveel woorde 'n Christelike standpunt na vore hoef te bring nie, maar die hele opset waarteenoor die skrywe plaasvind sal die Christelike verantwoording bring.

Teen hierdie agtergrond is dit vir „Koers" ' besondere groot eer om die Universiteit geluk te wens met sy honderdjarige bestaan. Graag rig ons ons gelukwense ook aan die Teologiese Skool van die Gereformeerde Kerk in Suid-Afrika as die moeder van die Universiteit. Mag die nuwe era wat nou betree word nie net heilsame ontwikkeling bring nie, maar ook verdere presisering, verdieping en uitvoering van die oorspronklike doelwitte. Sedert die veertiger jare het die groeikrag van die Universiteit vinniger opgelaai, en dit blyk seker te wees dat die sewentiger jare ' $n$ totale voorkomsverandering sal meebring. Hier dink ons nie net aan die geweldige bouprogram nie, maar ook aan die uitbouing van nuwe studierigtings. Dit is nie moeilik om te voorspel dat die P.U. vir C.H.O. binne die dekade wat ons nou binnegegaan het, 'n groot universiteit sal wees, met feitlik ' $n$ volledige beslag op alle studierigtings warin sy outoriteite belangstel.

Die redaksie van hierdie blad deel die wens en bede van die Rektor en al die dosente, oud-dosente, oud-studente en studente en belanghebbendes dat die innerlike groeikrag in dieselfde mate sigbaar sal wees. Die ideaal is tog dat die P.U. vir C.H.O. die kweekplek van leiers met beginsel sal wees en dat die roepstem van Potchefstroom ver en wyd oor ons land tot in die buiteland gehoor sal word. Aan hierdie doel wil „Koers" homself in beskeidenheid diensbaar maak.

W. N. Coetzee. 